\title{
Achievements of PVS (Primo Vascular System) Research from a Historical Perspective
}

\author{
Hoon-Gi Kim* \\ College of Liberal Arts, Hongik University, Seoul, Korea
}

Received June 28, 2021

Revised October 27, 2021

Accepted December 6, 2021

Correspondence to

Hoon-Gi Kim

College of Liberal Arts, Hongik

University, Seoul, Korea

E-mail wolfkim8@gmail.com

\begin{abstract}
The purpose of this paper is to compare the biological research carried out in North Korea with the modern outcomes in the same field, from a historical perspective. In the 1960s, the group led by Bong-Han Kim asserted the existence of a fundamental circulatory system in the human body. Their findings were introduced in five papers as well as in the newspaper Rodong Sinmun. The size of the group, the range of equipment, and their findings expanded gradually, and the final paper on blood cells would be only published one of over sixty papers reported at that time. In the five papers, some unclear and inconsistent contents were found. Meanwhile, in the 2000s, PVS (primo vascular system) researchers have published over one hundred papers to prove the existence of this novel system. Some trends have emerged in approximately sixty papers as follows: The research on the identification of the anatomical and histological characteristics has gradually expanded to encompass the system's own functioning. Also, new visual results (e.g. before and after dyeing, and its comparison with blood clots) and the exploration of possible medical applications (e.g. cancer metastasis channels or stem cells location) have been proposed. However, it is difficult to identify papers which comprehensively represented the elements claimed by Bong-Han Kim's group. In addition, papers have been published more in alternative or Oriental medicine journals than in Western biomedical journals. It seems necessary to report more existence of the system in one laboratory animal and in more influential journals.
\end{abstract}

Keywords: Bong-Han Kim, Fundamental circulatory system, PVS (primo vascular system), Historical perspective, Dyeing and microscopic observation, Anatomical and histological characteristics, Cancer metastasis, Stem cells

\section{INTRODUCTION}

In the 1960s, Professor Bong-Han Kim (1916-?) and his research group (hereafter the BK group) at the Pyongyang Medical College in North Korea asserted the existence of a fundamental circulatory system in the human body that was structurally and functionally distinct from the blood, lymphatic, and nervous systems in five papers [1-5]. They made the groundbreaking claim that the system must be the anatomical entity of the Kyungrak (acupuncture meridian) system of Oriental medicine, and that the sanals (live eggs) inside the system grew into cells through continuous renewal processes.

That claim, however, was not successfully confirmed in the international scientific community until a research group examining the primo vascular system (hereafter the PVS group) in South Korea started to report some anatomical evidence from laboratory animals in the early 2000s that strongly suggested the findings of the BK group were correct [6]. In March 2000, Professor Kwang-Sup Soh led a research group, which was called the Laboratory of Biomedical Physics for Korean Medicine, in the Department of Physics, Seoul National University, and began to represent the experimental results of the BK group from 2002. After obtaining meaningful data and observation techniques, the Professor Soh's group actively carried out demonstrations by visiting laboratories inside and outside the country, and formed international research networking [7]. In 2010, the group decided to call the Bonghan system as the PVS to promote more scientific meaning in the academic fields, and officially suggested to use that term during the first International Symposium on PVS, which was held with the government's support as a part of the activities at the Oriental Medicine Expo in Jaechon, South Korea [8]. In this paper, the term "PVS 
group" encompasses all domestic and foreign researchers, who have been studying on the claims of the BK group after leading reports and transmission of the Professor Soh's group.

Over the past twenty years, more than one hundred papers have been published in international academic journals, including ones registered with SCI (E) and SCOPUS, by the PVS group. For example, the group reported that they had succeeded in identifying the structures, which the BK group claimed to have found, in the lymphatic system [924] and the blood system [25-28], on the surfaces of internal organs [29-45], and inside the nervous system [46-55]. In addition, they hypothesized that the structures might be new cancer metastasis channels and showed some related experimental evidence [56-65]. One of the PVS subgroups, which started to study the PVS after visiting and demonstration of the Professor Soh's group and renamed the PVS to the HARNDS (hyaluronic-acid-rich node and duct system), even reported that there were many immune cells and stem cells in the structures of several body parts [66-69]. Furthermore, during this period, there were several turning points showing the quantitative and qualitative growth of the research. For example, the first International Symposium on PVS was successfully held in 2010 in South Korea, and its outcomes were published in a book by Springer in 2012 [70]. Additionally, themes centered on the PVS were dealt with as special issues in the journal Evidenced-Based Complementary and Alternative Medicine in 2013 and in 2015.

If the discoveries of the PVS group were true, the existence of a new circulatory system corresponding to the Kyungrak system in the body would be first proven in the world, and the PVS group would cast crucial implications for investigating the origin of stem cells as well as cancer metastasis mechanisms in the current biomedical field. However, until recently, the outcomes of the PVS group did not seem to have been widely accepted and expanded upon in the modern scientific community.

One reason for this may be found in the external dimension, such as the indifference and prejudice of the majority of the Western biomedical community against the studies on the Kyungrak system [7]. However, it is also necessary to examine another reason, one in the internal dimension, the scientific achievements themselves. As a large number of research papers does not guarantee the authenticity of their outcomes, the qualitative aspects of the papers by the PVS group should be validated, including whether they provided sufficient evidence to be accepted by the scientific community, what kinds of journals the papers were published in, and, basically, how accurately they represented the outcomes of the BK group. In fact, several review articles written by the PVS group [6,71-73] mainly showed evidence corresponding to the findings of BK group, as well as technical suggestions to identify the new system, but few studies have examined to what extent the outcomes of the BK group have been (un) successfully confirmed as a whole in those achieved by the PVS group. Moreover, little information has been provided concerning the formative process of the BK group's research. As the PVS group was attempting to represent the BK group's experiments, it is necessary to examine first how the BK group's discovery process was conducted.

The purpose of this paper is to examine historically the achievements of the PVS group compared with those accomplished by the BK group. On the one hand, I looked through five papers, four of which [1-4] were English versions containing colorful illustrations and microscopic photos, published by the BK group, as well as articles in the Rodong Sinmun, a newspaper published by the Worker's Party in North Korea, relating background stories not presented formally in the five papers. Stefanov [74] pointed out that there were insufficient explanations and inaccuracies with the current biological knowledge on the important points in five papers, and suggested hypotheses for the morphological architecture and the function of the PVS. In this paper, I indicate that the research process of the BK group was ongoing at that time, and that, as a result, some unclear and inconsistent statements had been described among the texts and visual materials. In fact, the BK group and many of their papers had suddenly disappeared before the research was finished. On the other hand, I selected about sixty papers published by the PVS group to determine how much of the characteristics of the new system argued by the BK group had been confirmed. Since one of the intentions in this paper is to compare the basic anatomical/histological characteristics presented by the two groups, I chose the papers of the PVS group with relatively well-defined basic characteristics through visual data. I also check on the kinds of journals in which the PVS group had published papers. As a result, I point out that, despite the PVS group's meaningful findings so far, there were aspects that did not fully prove the claims of the BK group, a potential factor in not so many papers being published in major Western biomedical journals. Finally, I suggest that it is necessary to demonstrate the existence of the PVS with more evidence from one animal and to report the outcomes in more influential journals.

\section{DEVELOPMENTS AND DISAPPEARANCE} OF THE EXPERIMENTS BYTHE BK GROUP

\section{Rapid growth and downfall of the group size and findings}

The paper in which the BK group first reported that they had discovered the material substance of Kyungrak was presented at a conference of the Pyongyang Medical 
College on August 8, 1961, and was published in Korean and in English in 1962 [1]. The author of the paper was Bong-Han Kim, but the BK group comprised six members from the Pyongyang Medical College. According to the Rodong Sinmun dated December 5, 1961, the group, which was first organized in October 1959, began researching the bioelectrical phenomenon through the Kyungrak and observed changes in the voltage at the Kyunghul (acupoints) on the skins of their bodies and those of rabbits using a selfmade instrument. After obtaining consistent results, i.e., the same constant regular repetitive curves at the Kyunghul that differed from the curves for other biological parts of the skin, through more than one hundred experiments conducted until February the following year, the group, now confident of the material substance's existence, started seeking it in earnest. It was said that, at first, the group found the oval-shaped tissues corresponding to the Kyunghul and, on August 18, finally succeeded in discovering the material pathway connections between the Kyunghul.

The BK group continued to study the physical distribution of the Kyungrak throughout the body, as well as the chemical composition inside them, and reported the results in their second paper in 1964 [2], which was authored by Bong-Han Kim and published by the Kyungrak Research Institute. The number of the group was the same as for the first paper, but their discoveries, particularly concerning the distribution inside the vessels, were surprisingly new. They reported, "We have also discovered the existence of structures inside the vessel, a fact which no one has ever conceived of...they are found in the blood and lymph in all vessels in a state of isolation, not adhering to the vessel wall" [2]. The Kyunghul and the connecting tubular structures between them were named Bonghan corpuscles and Bonghan ducts, respectively, in the second paper.

By the time the second paper was published, the size of the BK group had expanded greatly. According to the 1965 North Korean national central almanac, Chosun-JungangYeonkam, the Academy of Kyungrak, established in February 1964, consisted of about forty laboratories, and its president was Bong-Han Kim. In 1965, the third and fourth papers, which described the overall framework for the structures and functions of the Bonghan system, were published in the same journal [3,4], with authorship ascribed to the Academy of Kyungrak, led by Bong-Han Kim, in the table and end part of Korean and English version.

The fifth paper, published in Korean in 1965, reported on the renewal cycling process of the blood cells as one specific example of the fourth paper's theory of sanal. The paper was not the last one written, nor did it signal the end of the research, but is it the last remaining one. According to the Rodong Sinmun on October 9, 1965, the fifth paper was only one of over sixty papers presented at the conference of the Academy of Kyungrak, which was held from October 4 to 8 . The newspaper article described the main points at the conference:

The newly published papers were more than sixty covering broad areas of biology and medicine, including theoretical biology, genetics, cytology, developmental biology, physiology, biochemistry, microbiology, anatomy, histology, pathology and experimental therapy. What drew particular attention from the papers presented at this academic presentation was that new theories on pathology and experimental therapeutic achievements have been established based on the theory of sanal...Among the papers presented at the conference, we first published a summary on the $<$ Bonghan Sanal-Cell Cycle $>$ of blood cells.

However, the experimental results presented at the conference as well as any remarks about the BK group in the Rodong Sinmun and Chosun-Jungang-Yeonkam disappeared abruptly in North Korea around 1966. There has been much speculation about the study's downfall, but the cause does not seem to have been a matter of scientific performance.

\section{Undisclosed research methods for discovery}

The BK group did not explain in the five papers the specific methods for discovering the structures. According to the Rodong Sinmun dated December 5, 1961, the experiments were conducted in an enclosed, dark room with low air circulation. After the group discovered the structures, it was said that they also succeeded in staining them, allowing them to be clearly identified. However, it is hard to guess what the dye was, or how the structures had been found in the darkroom without first dyeing them. In the first paper, it was only reported that they "succeeded in correctly discovering Kyunghul by the method we ourselves initiated and found out that its distribution tallies in the main with the distribution of Kyunghul indicated in the classics" [1]. A similarly vague description was used in the second paper: "by the vivistaining method and by the unique external appearance of the Kyunghul position we could unmistakably single out the Bonghan corpuscles" [2].

The BK group did not seem to have informed foreign visiting scientists of how to discover the new structures. For example, in May 1965, the Ministry of Health of Russia sent two scientists to the Academy of Kyungrak [75]. After returning to Russia, they proposed that it was necessary to send young scientists to the Academy of Kyungrak for training, as well as to establish two laboratories for studying the meridian system in Moscow. However, this attempt was ideologically thwarted by fierce opposition from a cytologist, 
Vladimir Yakovlevich Alexandrov, a powerful leader in the Russian scientific community at that time. In the case of China, several institutes, including the Institute of MeridianCollaterals in Beijing, tried to prove the claims of the $\mathrm{BK}$ group on human bodies, rabbits, mice, pigs, and monkeys, but they had considerable difficulties because the BK group's papers provided no specific methods [76]. In 1963, a group of leading Chinese anatomists, histologists, physiologists, and pathologists twice visited the laboratory of the BK group, but they did not learn how the experiments were conducted. Because the methods were not disclosed, associated studies could not be easily attempted, and several cases have assessed the outcomes of the BK group as fake without any experimental trials [77].

Instead, the BK group suggested many ways to identify the characteristics of the new structures. They determined that the new structures were spread like a net over the body during exploration processes following the discovery of the superficial structures, i.e., the profound structures were discovered in the process of investigating what the superficial structures were connected to. According to an article written by one of the BK group scientists in the Rodong Sinmun dated July 30, 1965, the external and the internal Bonghan corpuscles were found in the process of studying the distribution of the ducts connected to the superficial Bonghan corpuscles. In the same way, the intra-external and neural Bonghan corpuscles were found while following the respective ducts. Furthermore, the intra-organic and terminal Bonghan corpuscles were discovered while determining where the Bonghan ducts ended. Every time a new discovery was made, the BK group identified the anatomical and histological characteristics of the structures. Beginning with the second paper, the BK group actively applied contemporary cutting-edge research methods of Western science and

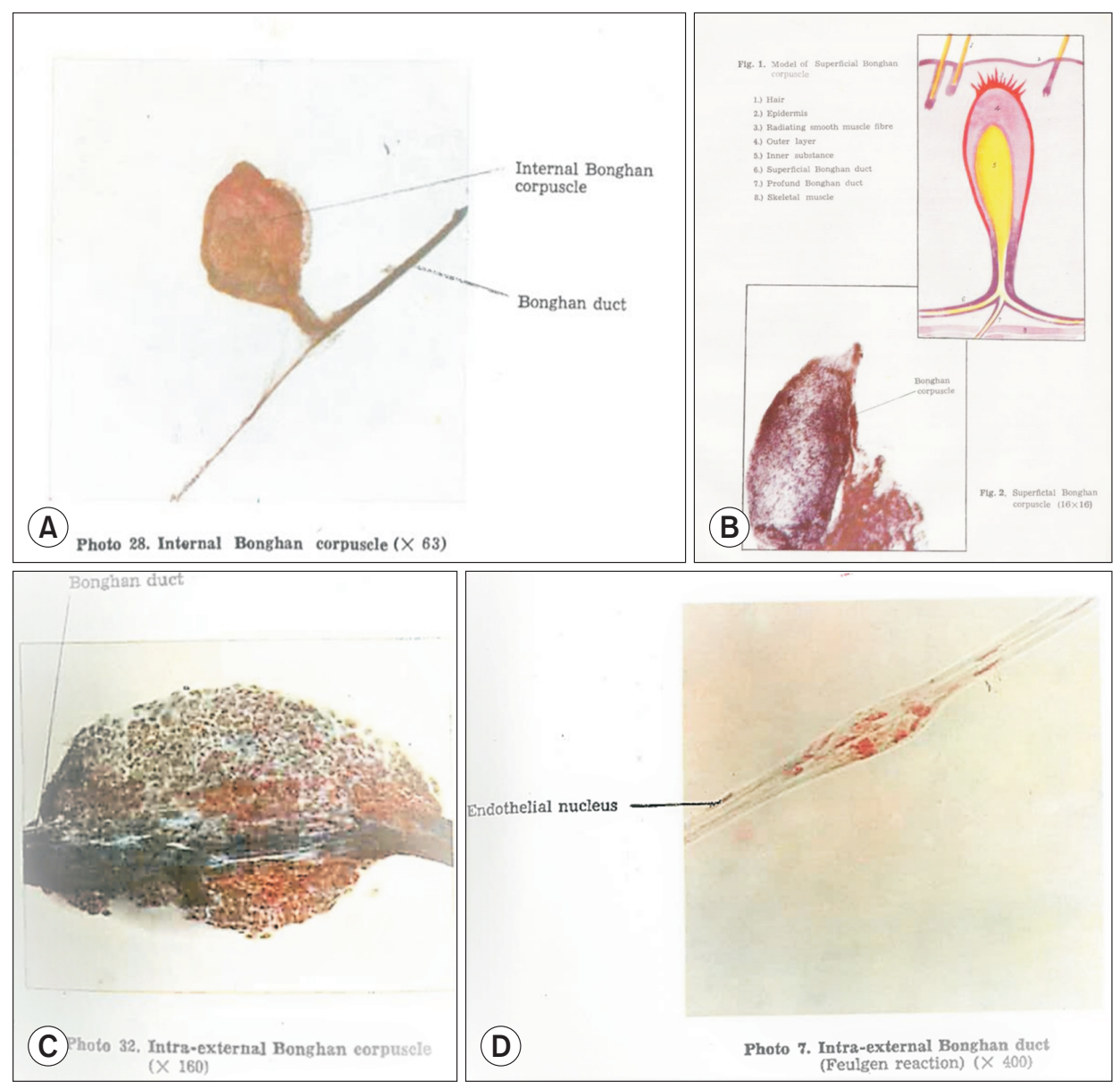

Fig. 1. Uncommon visual materials of the Bonghan structures. There were some uncommon visual materials about the Bonghan structures in the papers. For example, the photo of the internal Bonghan corpuscle (A) in the third paper would not be the typical one. Rather, it looked like the superficial one (B) as shown in the illustration and photo of the second paper. Also, the photo of the intra-external Bonghan corpuscle $(C)$ in the third paper did not seem to be the common one because it looked like that one duct was penetrated into some unknown tissues. In the case of the photo of the intra-external duct (D) in the third paper, it seemed to be the corpuscle rather than the typical duct. All visual materials were from the ISPVS website (www. ispvs.org) accessed in July, 2020. 
technology. The structures and functions of the Bonghan system were investigated in detail using various dyes, advanced microscopes, such as phase-contrast, stereoscope, and electron microscopes, radioactive isotope tracking devices, and many biochemical test techniques.

For example, the BK group applied Chargaff's rules (19052002), which provided an important inspiration to James Watson and Francis Crick, who published a famous paper suggesting the form of DNA as a double helix in Nature in 1953, to estimate the ratios of DNA and RNA in the sanals. The group found that the amount of purine bases and that of pyrimidine were equal to that of normal nucleic acids, and they proposed that one sanal would correspond to one chromosome in a cell [4]. Another example was their use of a radioisotope $\left(\mathrm{P}^{32}\right)$ in their second paper to show that the Bonghan system was a circulatory system. They injected the radioisotope into the Bonghan corpuscles in the skin of the abdominal wall and could observe a nearly straight line with high radioactivity without any sideways dispersion. In addition, most of the staining methods they employed are still widely used in modern science and technology communities [72].

\section{Inconsistent expressions}

The five papers included more than one hundred and fifty photos and illustrations that showed the structures and functions of the Bonghan system. Whenever a new paper was published, it included more accurate visual data. However, there were some inconsistent expressions among the texts and visual materials in the five papers.

First, some structures in the photos seemed not to match the descriptions in the texts and other visual materials. For example, the internal Bonghan corpuscle reported in the third paper, as shown in Fig. 1A, looked more like a superficial Bonghan corpuscle, as shown in Fig. 1B in the second paper, because the ducts were connected to one side of it. Also, according to the text in the second paper, the profound Bonghan corpuscle "is a long fusiform one (cucumber shape) with blunt ends or an oval form" and "Both ends of the Bonghan corpuscle are connected with the Bonghan duct" [2]. Additionally, one duct of the internal Bonghan corpuscle was thicker than the other, which was not described in the text. Another example was found in the case of the intraexternal Bonghan corpuscle of the third paper, as shown in Fig. 1C. The duct appears to penetrate a corpuscle, as if some tissues had attached around the duct rather than the common corpuscle. In addition, the middle part of the intra-external Bonghan duct in the third paper, as shown in Fig. 1D, which was found on the surface of the internal organ, was somewhat convex, so that it looked more like a corpuscle than a typical duct.

Second, the state of connection between the Bonghan structures and the cells was depicted inconsistently. For example, an illustration of the terminal Bonghan corpuscles
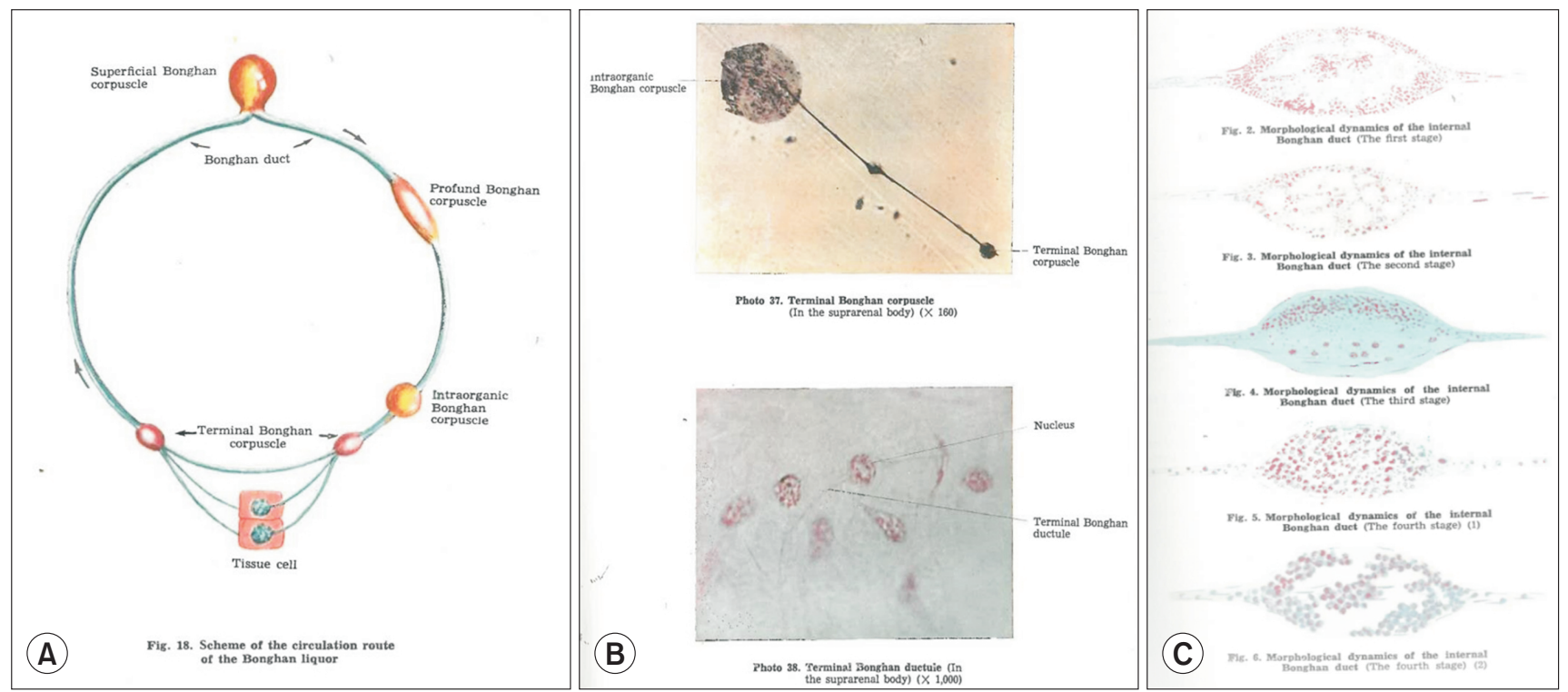

Fig. 2. The connection between the Bonghan system and cells. There was some inconsistent depiction about location of the cells from the sanals in the third paper. The illustration about the total cycle of the Bonghan liquor (A) showed that the terminal Bonghan ductles were connected to two sides of a cell, but, in the photos of them (B), there was only one ductle joined to a cell. Throughout the papers, it was generally described that the sanals went out through the ductles, and the cells grown from them inside the Bonghan system became to locate at some related tissues outside the Bonghan system, for example, in the lymphatic vessel (C). All visual materials were from the ISPVS website (www.ispvs.org) accessed in July, 2020. 
and ductles in the third paper, as shown in Fig. 2A, showed that they were connected to two sides of the nucleus of a cell; one was in the nucleus, and the other was out of the nucleus. However, in the photos of the same paper, as shown in Fig. $2 \mathrm{~B}$, the terminal Bonghan ductles seem to be connected to only one side of the nucleus. According to the conclusion of the fourth paper, the sanals "grow mature and come out of the cell, breaking the cell membrane" and "while moving through them (Bonghan ducts), grow into nucleus-like structures, which become cells in the relevant tissues" [4]. If this is correct, the terminal Bonghan ductles would perform the role of the first gateway for the sanals to grow into cells and should be connected to one side of the cells. Moreover, the cells would be located in the tissues outside the Bonghan system, as depicted in Fig. 2C of the third paper, which showed that the sanals of the internal Bonghan corpuscle in the lymphatic vessel grew into cells and went out "through the holes of the destroyed outer membrane" [3].

\section{OUTCOMES OF THE PVS GROUP COMPARED WITH THOSE OF THE BK GROUP}

\section{Incomplete confirmation and reports}

There have been many meaningful discoveries about Bonghan corpuscles and ducts reported in the papers of the PVS group. However, as a whole, it was not easy to find cases that showed most of the major characteristics at the same time in one paper (Table 1).

The biological tissues where the findings about the Bonghan system had been reported were the surface of the internal organs (17), the lymphatic vessels (16), the nervous system (10), the blood vessels (4) and several parts (4). However, none of these fifty-one papers identified all the major anatomical and histological characteristics, nor all the components of the internal materials. Furthermore, several cases did not report the basic characteristics of the Bonghan system. For example, only twenty-two papers (internal organs, 11; blood vessels, 4; lymphatic vessels, 3; nervous system, 2; and several parts, 2) showed the presence of the Bonghan ductles, and thirty-five papers (internal organs, 11; lymphatic vessels, 10; nervous system, 7; several parts, 4; and blood vessels, 3) reported the connection among the ducts and the corpuscles. Thirty-one papers (lymphatic vessels, 12; nervous system, 9; internal organs, 6; and blood vessels, 4) presented the rod-shaped nuclei of the endothelial cells. In addition, there were fewer reports of internal substances implying the function of the system. For example, in the cases of the internal materials, seven papers (internal organs, 5; nervous system, 2) reported the existence of DNA granules inside the Bonghan ductles, and five papers (internal organs, 4;

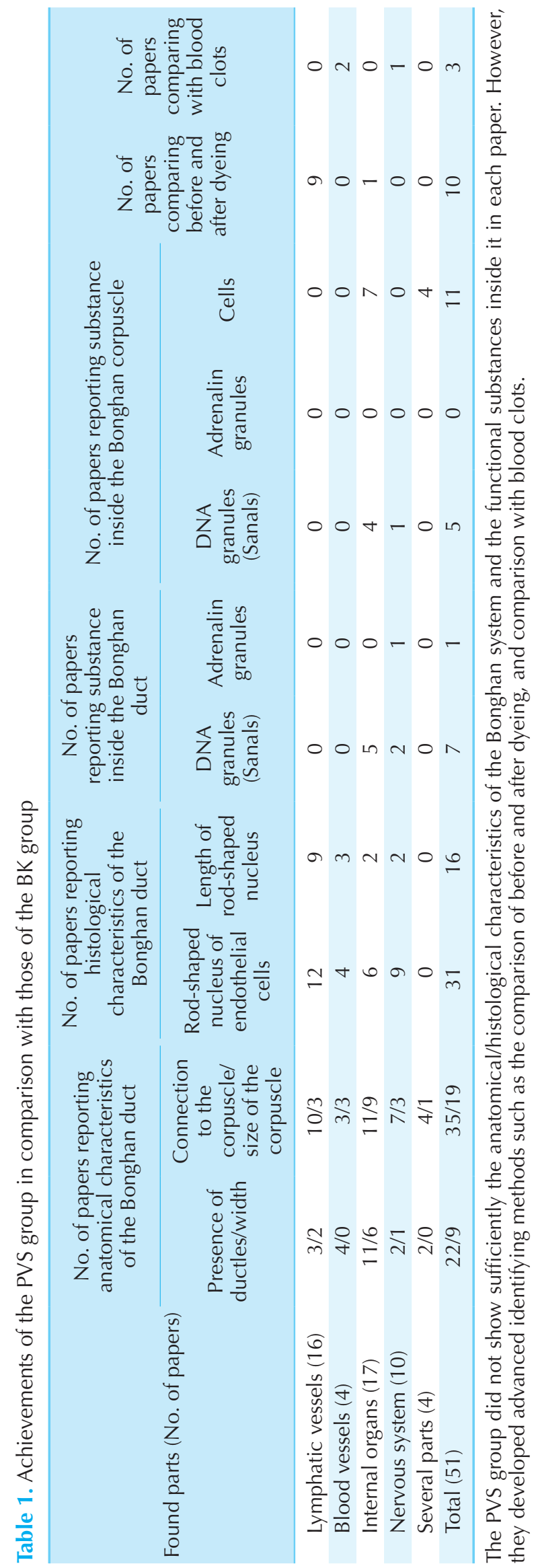

www.journal-jams.org 
nervous system, 1) showed the DNA granules in the Bonghan corpuscles. By comparison, the existence of the cells in the corpuscles has been reported relatively more. For example, seven papers presented various types of the cells, including cells with adrenalin granules, in the internal organs, and four papers studying several parts reported the presence of immune cells and stem cells. This situation of not meeting the basic requirements of the Bonghan structures suggested by the BK group did not improve significantly over time.

Not many structures were clearly reported in one laboratory animal, too. According to the claims of the BK group, there were a great many structures all over the body, but, except in a few cases $[15,18,28,39]$, about three or less structures per animal were reported in their papers. In addition, there were cases that the number of animals and structures was not reported at all, or unclear statements such as "over 100 animals" or "many structures" were used.

\section{New approaches for visualization and medical applications}

Since the BK group did not provide information on the research methods to discover the new structures, the PVS group had to undertake numerous trials and errors to observe their existence. In the process, they developed their own definite methods to discover the structures, and suggested new medical applications for them.

First, the PVS group developed several ways to clearly show that the new structures they found were different from blood vessels, lymphatic vessels, and nerve tissues. For example, ten papers showed the comparison of these tissues before and after staining, and three papers presented the differences between the new structures and the blood clots treating specific dyes they developed (Table 1). They even suggested an optical method to find the structures floating in a lymph vessel without any staining [13].

Second, the PVS group sought to determine the structures in cancer tissues and suggested that the structures could be new cancer metastasis channels in addition to blood and lymphatic vessels [56-65]. One sub-group of the PVS group reported that, through investigating the new structures in several body parts, they found not only various immune cells but also pluripotent adult stem cells able to repair some injured tissues, the location of which had not been well known [66-69]. The group filed a patent for the relevant research (HAR-NDS-derived stem cells, method for separating same, and use thereof, US2020/0138859 A1) in the U.S. in 2020.

\section{Publishing trends of the papers}

Some characteristic trends were revealed in regard to the kinds of academic journals in which the PVS group published its papers. As a whole, not many of their papers were published in major biomedical journals. For example, of their sixty-seven papers which were published until recently [969,78-83], twenty-one were published in Western biology and medicine journals (Table 2). In addition, eight papers were published in Western scientific journals dealing with physics and observation techniques. On the other hand, thirty-eight papers were reported in alternative or Oriental medicine journals. This trend was similar in terms of time, as the number of papers published in Western biomedical journals did not increase relatively as time passed.

Regardless of the fields the journals represented, the number of papers published in a year did not continuously increase. From 2007 to 2015, about four to ten papers were published annually, but the number decreased beginning in 2016. Although several review papers on the experimental

Table 2. Trends of the journals published by the PVS group

\begin{tabular}{|c|c|c|c|}
\hline \multirow{2}{*}{$\begin{array}{l}\text { Found parts } \\
\text { (No. of papers) }\end{array}$} & \multicolumn{3}{|c|}{ Published year/No. of papers (No. of total papers) } \\
\hline & Western biology/medicine & $\begin{array}{l}\text { Other sciences including physics, } \\
\text { observation methods }\end{array}$ & $\begin{array}{l}\text { Alternative medicine/oriental } \\
\text { medicine }\end{array}$ \\
\hline $\begin{array}{l}\text { Lymphatic vessels } \\
\text { (16) }\end{array}$ & $2005 / 1,2006 / 1,2008 / 1$ (3) & 2007/1 (1) & $\begin{array}{c}2007 / 1,2012 / 2,2013 / 3 \\
2014 / 2,2015 / 4(12)\end{array}$ \\
\hline Blood vessels (5) & $2004 / 1,2008 / 2,2011 / 1(4)$ & $-/ 0(0)$ & $2019 / 1(1)$ \\
\hline Internal organs (22) & $2005 / 1,2016 / 1,2019 / 2(4)$ & $\begin{array}{l}2007 / 2,2008 / 1,2010 / 1 \\
2016 / 1,2021 / 1(6)\end{array}$ & $\begin{array}{c}2008 / 2,2009 / 3,2013 / 3 \\
2015 / 2,2020 / 2(12)\end{array}$ \\
\hline Nervous system (10) & $2011 / 1,2012 / 1,2015 / 1$ (3) & $-/ 0(0)$ & $2008 / 1,2010 / 3,2012 / 2,2013 / 1(7)$ \\
\hline Cancer tissues (10) & 2010/1, 2013/1, 2014/1 (3) & $2010 / 1(1)$ & 2009/1, 2011/2, 2013/2, 2015/1 (6) \\
\hline Several parts (4) & $2012 / 1,2014 / 2,2018 / 1$ (4) & $-/ 0(0)$ & $-/ 0(0)$ \\
\hline Total (67) & 21 & 8 & 38 \\
\hline
\end{tabular}

The papers of the PVS group were more published in the journals of alternative or Oriental Medicine than ones of Western biomedicine. Also, the number of the papers did not increase while several review papers dealing with research methodology had been published. 
methodologies for representing the new structures had been steadily published, the number of papers was not affected much. For example, in the case of the lymphatic vessels, from 2012 to 2015 four of sixteen papers $[14,17,19,24]$ presented experimental protocols, which mainly pointed out the rodshaped nuclei as characteristics of the Bonghan structures using alcian blue in rabbits, rats, and mice. Review papers were also published on the areas of cancer tissues [64] and several body parts [69] exploring functional aspects of the Bonghan system.

\section{DISCUSSION AND SUGGESTIONS}

Although the BK group claimed that they first discovered the material substance of the Kyungrak system, there were different aspects between the characteristics of the Kyungrak system and what they observed. For example, as the BK group mentioned in the second paper, the Bonghan corpuscles and ducts were located all over the body, even in the blood and lymphatic vessels, as well as under the epidermis where the Kyunghul, in Oriental medicine, were generally known to be distributed. In addition, they identified this new system as a "multi-circulation system," which had independent circulatory passages complexly linked to each other, unlike the meridian system in Oriental medicine [3]. Therefore, the scientific significance would be that the BK group strongly suggested the possibility of discovering a new fundamental circulatory system, rather than first discovering the material substance corresponding to the Kyungrak system.

Of course, there were several unclear and inconsistent statements throughout the five papers. However, it is necessary to remember that the BK group's research abruptly stopped while it was moving toward completion. If their research had continued, the outcomes would potentially have been reported more consistently, and their methods for identifying the new structures could have been reported.

Although the PVS group actively attempted to prove experimentally the claims of the BK group, until recently, insufficient scientific evidence appears to have been presented in their papers. Nevertheless, the importance of the new research methods and biomedical knowledge achieved by the PVS group cannot be denied. As was the case with the BK group, it was very significant for the PVS group to have successfully discovered new structures in the body that were different from what had been known.

Until recently, the discoveries about the new biological structures were still being reported in the West. For example, in 2015, one research group claimed that they found lymphatic vessels in the membrane of a mouse's brain, contrary to established academic orthodoxy [84]. In 2017, a paper confirming the existence of lymphatic vessels in the human brain was published [85]. These discoveries of anatomical structures in new sites have led to the development of new treatments for incurable illnesses, such as Alzheimer's disease [86]. In 2018, another research group suggested the interstitium, which is a contiguous fluid-filled space existing between structural barriers, as a new organ [87]. Recently, this group proposed the role of the interstitium as a channel of cancer metastasis [88].

The achievements of the PVS group do not seem to lag behind compared to those mentioned above. Even if the existence of the Bonghan system was not fully represented, it would be worthy of notice from Western biological journals to report that there is a new biological system that consists of unique tissues interconnected and spread throughout the body, one that is clearly distinguished from the blood, lymphatic, and nervous systems without any artifacts. To do so, it would be necessary to develop experimental methods for subsequent researchers showing much more structural and functional evidence per laboratory animal in one paper.

\section{ACKNOWLEDGEMENTS}

I express my special thanks to the committee of ISPS2021, held from May 27 to 29 in 2021, for giving me a chance to present the draft of this paper, which included some contents of my recently published book.

\section{CONFLICT OF INTEREST}

The author declares no conflict of interest.

\section{ORCID}

Hoon-Gi Kim, https://orcid.org/0000-0001-5773-349X

\section{REFERENCES}

1. Kim BH. Great Discovery in Biology and Medicine: Substance of Kyungrak. Pyongyang: Foreign Languages Publishing House, 1962.

2. Kim BH. On the Kyungrak System. Pyongyang: The Kyungrak Research Institute, 1964.

3. The Academy of Kyungrak. Kyungrak system. Proc Acad Kyungrak DPRK 1965;2:9-67.

4. The Academy of Kyungrak. Theory of sanal. Proc Acad Kyungrak DPRK 1965;2:69-104.

5. The Academy of Kyungrak. Bonghan sanal-cell cycle of blood cells. Chosun Med 1965;12:1-6.

6. Soh KS, Kang KA, Ryu YH. 50 years of Bong-Han theory and 10 years of primo vascular system. Evid Based Complement Alternat Med 2013;2013:587827. 
7. Kim HG. Formative research on the primo vascular system and acceptance by the Korean scientific community: the gap between creative basic science and practical convergence technology. J Acupunct Meridian Stud 2013;6:319-30.

8. Kang KA. Historical observations on the half-century freeze in research between the Bonghan system and the primo vascular system. J Acupunct Meridian Stud 2013;6:285-92.

9. Lee BC, Yoo JS, Baik KY, Kim KW, Soh KS. Novel threadlike structures (Bonghan ducts) inside lymphatic vessels of rabbits visualized with a Janus Green B staining method. Anat Rec B New Anat 2005;286:1-7.

10. Lee C, Seol SK, Lee BC, Hong YK, Je JH, Soh KS. Alcian blue staining method to visualize bonghan threads inside large caliber lymphatic vessels and x-ray microtomography to reveal their microchannels. Lymphat Res Biol 2006;4:181-90.

11. Johng HM, Yoo JS, Yoon TJ, Shin HS, Lee BC, Lee C, et al. Use of magnetic nanoparticles to visualize threadlike structures inside lymphatic vessels of rats. Evid Based Complement Alternat Med 2007;4:77-82.

12. Yoo JS, Johng HM, Yoon TJ, Shin HS, Lee BC, Lee C, et al. In vivo fluorescence imaging of threadlike tissues (Bonghan ducts) inside lymphatic vessels with nanoparticles. Curr Appl Phys 2007;7:342-8

13. Lee BC, Soh KS. Contrast-enhancing optical method to observe a Bonghan duct floating inside a lymph vessel of a rabbit. Lymphology 2008;41:178-85.

14. Jung SJ, Cho SY, Bae KH, Hwang SH, Lee BC, Kim S, et al. Protocol for the observation of the primo vascular system in the lymph vessels of rabbits. J Acupunct Meridian Stud 2012;5:234-40.

15. Noh YI, Rho M, Yoo YM, Jung SJ, Lee SS. Isolation and morphological features of primo vessels in rabbit lymph vessels. J Acupunct Meridian Stud 2012;5:201-5.

16. Huh H, Lee BC, Park SH, Yoon JW, Lee SJ, Cho EJ, et al. Composition of the extracellular matrix of lymphatic novel threadlike structures: is it keratin? Evid Based Complement Alternat Med 2013;2013:195631.

17. Jung SJ, Bae KH, Nam MH, Kwon HM, Song YK, Soh KS. Primo vascular system floating in lymph ducts of rats. J Acupunct Meridian Stud 2013;6:306-18.

18. Noh YI, Yoo YM, Kim RH, Hong YJ, Lee HR, Rho MS, et al. Observation of a long primo vessel in a lymph vessel from the inguinal node of a rabbit. Evid Based Complement Alternat Med 2013;2013:429106.

19. Jung SJ, Lee SH, Bae KH, Kwon HM, Song YK, Soh KS. Visualization of the primo vascular system afloat in a lymph duct. J Acupunct Meridian Stud 2014;7:337-45.

20. Park SY, Chang BS, Lee SH, Yoon JH, Kim S, Soh KS. Observation of the primo vessel approaching the axillary lymph node with the fluorescent dye, DiI. Evid Based Complement Alternat Med 2014;2014:287063.

21. Carlson E, Perez-Abadia G, Adams S, Zhang JZ, Kang
KA, Maldonado C. A novel technique for visualizing the intralymphatic primo vascular system by using hollow gold nanospheres. J Acupunct Meridian Stud 2015;8:294-300.

22. Kim DU, Han JW, Jung SJ, Lee SH, Cha R, Chang BS, et al. Comparison of alcian blue, trypan blue, and toluidine blue for visualization of the primo vascular system floating in lymph ducts. Evid Based Complement Alternat Med 2015;2015:725989.

23. Lee HR, Rho MS, Hong YJ, Ha YE, Kim JY, Noh YI, et al. Primo vessel stressed by lipopolysaccharide in rabbits. J Acupunct Meridian Stud 2015;8:301-6.

24. Park SY, Jung SJ, Bae KH, Soh KS. Protocol for detecting the primo vascular system in the lymph ducts of mice. J Acupunct Meridian Stud 2015;8:321-8.

25. Lee BC, Baik KY, Johng HM, Nam TJ, Lee J, Sung B, et al. Acridine orange staining method to reveal the characteristic features of an intravascular threadlike structure. Anat Rec B New Anat 2004;278:27-30.

26. Lee BC, Yoo JS, Baik KY, Sung B, Lee J, Soh KS. Development of a fluorescence stereomicroscope and observation of Bong-Han corpuscles inside blood vessels. Indian J Exp Biol 2008;46:330-5.

27. Yoo JS, Kim MS, Ogay V, Soh KS. In vivo visualization of bonghan ducts inside blood vessels of mice by using an Alcian blue staining method. Indian J Exp Biol 2008;46:336-9.

28. Lee BC, Kim HB, Sung B, Kim KW, Sohn J, Son B, et al. Network of endocardial vessels. Cardiology 2011;118:1-7.

29. Shin HS, Johng HM, Lee BC, Cho SI, Soh KS, Baik KY, et al. Feulgen reaction study of novel threadlike structures (Bonghan ducts) on the surfaces of mammalian organs. Anat Rec B New Anat 2005;284:35-40.

30. Kwon J, Baik KY, Lee BC, Soh KS, Lee NJ, Kang CJ. Scanning probe microscopy study of microcells from the organ surface Bonghan corpuscle. Appl Phys Lett 2007;90:173903.

31. Lee BC, Yoo JS, Ogay V, Kim KW, Dobberstein H, Soh KS, et al. Electron microscopic study of novel threadlike structures on the surfaces of mammalian organs. Microsc Res Tech 2007;70:3443.

32. Kim J, Ogay V, Lee BC, Kim MS, Lim I, Woo HJ, et al. Catecholamine-producing novel endocrine organ: Bonghan system. Med Acupunct 2008;20:97-102.

33. Lee SJ, Lee BC, Nam CH, Lee WC, Jhang SU, Park HS, et al. Proteomic analysis for tissues and liquid from Bonghan ducts on rabbit intestinal surfaces. J Acupunct Meridian Stud 2008;1: 97-109.

34. Sung B, Kim MS, Lee BC, Yoo JS, Lee SH, Kim YJ, et al. Measurement of flow speed in the channels of novel threadlike structures on the surfaces of mammalian organs. Naturwissenschaften 2008;95:117-24.

35. Lee BC, Kim KW, Soh KS. Visualizing the network of Bonghan ducts in the omentum and peritoneum by using Trypan blue. J Acupunct Meridian Stud 2009;2:66-70.

36. Lee BC, Jhang SU, Choi JH, Lee SY, Ryu PD, Soh KS. DiI 
staining of fine branches of Bonghan ducts on surface of rat abdominal organs. J Acupunct Meridian Stud 2009;2:301-5.

37. Ogay V, Bae KH, Kim KW, Soh KS. Comparison of the characteristic features of Bonghan ducts, blood and lymphatic capillaries. J Acupunct Meridian Stud 2009;2:107-17.

38. Kim MS, Oh SW, Lim JH, Han SW. Phase contrast x-ray microscopy study of rabbit primo vessels. Appl Phys Lett 2010; 97:213703.

39. Lee HS, Lee JY, Kang DI, Kim SH, Lee I, Park SH, et al. Evidence for the primo vascular system above the epicardia of rat hearts. Evid Based Complement Alternat Med 2013;2013:510461.

40. Lim CJ, Yoo JH, Kim Y, Lee SY, Ryu PD. Gross morphological features of the organ surface primo-vascular system revealed by hemacolor staining. Evid Based Complement Alternat Med 2013;2013:350815.

41. Park ES, Lee JH, Kim WJ, Heo J, Shin DM, Leem CH. Expression of stem cell markers in primo vessel of rat. Evid Based Complement Alternat Med 2013;2013:438079.

42. Gil H, Bae KH, Kim L, Kim S, Soh KS. Number density of mast cells in the primo nodes of rats. J Acupunct Meridian Stud 2015;8:288-93.

43. Yoo YY, Jung GE, Kwon HM, Bae KH, Cho SJ, Soh KS. Study of mast cells and granules from primo nodes using scanning ionic conductance microscopy. J Acupunct Meridian Stud 2015;8:281-7.

44. Sohn JH, Yoon JH, Kim YJ, Kim MK, Kim JH, Kwon O, et al. Tubular structures believed to be meridian line found from the membrane of abdominal wall in rabbit. J Investig Cosmetol 2016;12:295-8.

45. Vodyanoy V, Pustovyy O, Globa L, Sorokulova I. Evaluation of a new vasculature by high resolution light microscopy: primo vessel and node. ArXiv [Preprint] 2016. Available from: https:// arxiv.org/abs/1608.04276.

46. Lee BC, Kim S, Soh KS. Novel anatomic structures in the brain and spinal cord of rabbit that may belong to the Bonghan system of potential acupuncture meridians. J Acupunct Meridian Stud 2008;1:29-35.

47. Jia ZF, Lee BC, Eom KH, Cha JM, Lee JK, Su ZD, et al. Fluorescent nanoparticles for observing primo vascular system along sciatic nerve. J Acupunct Meridian Stud 2010;3:150-5.

48. Lee BC, Eom KH, Soh KS. Primo-vessels and primo-nodes in rat brain, spine and sciatic nerve. J Acupunct Meridian Stud 2010;3:111-5.

49. Lee BC, Kim KW, Soh KS. Characteristic features of a nerve primo-vessel suspended in rabbit brain ventricle and central canal. J Acupunct Meridian Stud 2010;3:75-80.

50. Dai J, Lee BC, An P, Su Z, Qu R, Eom KH, et al. In situ staining of the primo vascular system in the ventricles and subarachnoid space of the brain by trypan blue injection into the lateral ventricle. Neural Regen Res 2011;6:2171-5.

51. Lee HS, Lee BC. Visualization of the network of primo vessels and primo nodes above the pia mater of the brain and spine of rats by using Alcian blue. J Acupunct Meridian Stud 2012;5:21825.

52. Lee HS, Park WH, Je AR, Kweon HS, Lee BC. Evidence for novel structures (primo vessels and primo nodes) floating in the venous sinuses of rat brains. Neurosci Lett 2012;522:98-102.

53. Moon SH, Cha R, Lee M, Kim S, Soh KS. Primo vascular system in the subarachnoid space of the spinal cord of a pig. J Acupunct Meridian Stud 2012;5:226-33.

54. Moon SH, Cha R, Lee GL, Lim JK, Soh KS. Primo vascular system in the subarachnoid space of a mouse brain. Evid Based Complement Alternat Med 2013;2013:280418.

55. Lee HS, Kang DI, Yoon SZ, Ryu YH, Lee I, Kim HG, et al. Evidence for novel age-dependent network structures as a putative primo vascular network in the dura mater of the rat brain. Neural Regen Res 2015;10:1101-6.

56. Yoo JS, Kim HB, Ogay V, Lee BC, Ahn S, Soh KS. Bonghan ducts as possible pathways for cancer metastasis. J Acupunct Meridian Stud 2009;2:118-23.

57. Yoo JS, Ayati MH, Kim HB, Zhang WB, Soh KS. Characterization of the primo-vascular system in the abdominal cavity of lung cancer mouse model and its differences from the lymphatic system. PLoS One 2010;5:e9940.

58. Yoo JS, Kim HB, Won N, Bang J, Kim S, Ahn S, et al. Evidence for an additional metastatic route: in vivo imaging of cancer cells in the primo-vascular system around tumors and organs. Mol Imaging Biol 2011;13:471-80.

59. Heo C, Hong MY, Jo A, Lee YH, Suh M. Study of the primo vascular system utilizing a melanoma tumor model in a green fluorescence protein expressing mouse. J Acupunct Meridian Stud 2011;4:198-202.

60. Hong M, Park SS, Do H, Jhon GJ, Suh M, Lee Y. Primo vascular system of murine melanoma and heterogeneity of tissue oxygenation of the melanoma. J Acupunct Meridian Stud 2011; 4:159-63.

61. Islam MA, Thomas SD, Sedoris KJ, Slone SP, Alatassi H, Miller DM. Tumor-associated primo vascular system is derived from xenograft, not host. Exp Mol Pathol 2013;94:84-90.

62. Lee S, Lim J, Cha J, Lee JK, Ryu YH, Kim S, et al. Differentiating blood, lymph, and primo vessels by residual time characteristic of fluorescent nanoparticles in a tumor model. Evid Based Complement Alternat Med 2013;2013:632056.

63. Lim J, Lee S, Su Z, Kim HB, Yoo JS, Soh KS, et al. Primo vascular system accompanying a blood vessel from tumor tissue and a method to distinguish it from the blood or the lymph system. Evid Based Complement Alternat Med 2013;2013:949245.

64. Yoo JS, Soh KS. A transformative approach to cancer metastasis: primo vascular system as a novel microenvironment for cancer stem cells. Cancer Cell Microenviron 2014;1:e142.

65. Ping A, Zhendong S, Rongmei Q, Jingxing D, Wei C, Zhongyin $Z$, et al. Primo vascular system: an endothelial-to-mesenchymal potential transitional tissue involved in gastric cancer meta- 
stasis. Evid Based Complement Alternat Med 2015;2015:812354.

66. Kwon BS, Ha CM, Yu S, Lee BC, Ro JY, Hwang S. Microscopic nodes and ducts inside lymphatics and on the surface of internal organs are rich in granulocytes and secretory granules. Cytokine 2012;60:587-92.

67. Hwang S, Lee SJ, Park SH, Chitteti BR, Srour EF, Cooper S, et al. Nonmarrow hematopoiesis occurs in a hyaluronic-acid-rich node and duct system in mice. Stem Cells Dev 2014;23:2661-71.

68. Lee SJ, Park SH, Kim YI, Hwang S, Kwon PM, Han IS, et al. Adult stem cells from the hyaluronic acid-rich node and duct system differentiate into neuronal cells and repair brain injury. Stem Cells Dev 2014;23:2831-40.

69. Rai R, Chandra V, Kwon BS. A hyaluronic acid-rich node and duct system in which pluripotent adult stem cells circulate. Stem Cells Dev 2015;24:2243-58.

70. Soh KS, Kang KA, Harrison DK. The Primo Vascular System: Its Role in Cancer and Regeneration. New York: Springer, 2011.

71. Soh KS. Bonghan circulatory system as an extension of acupuncture meridians. J Acupunct Meridian Stud 2009;2:93-106.

72. Vodyanoy V, Pustovyy O, Globa L, Sorokulova I. Primovascular system as presented by Bong Han Kim. Evid Based Complement Alternat Med 2015;2015:361974.

73. Kang KA, Maldonado C, Vodyanoy V. Technical challenges in current primo vascular system research and potential solutions. J Acupunct Meridian Stud 2016;9:297-306.

74. Stefanov M. Critical review and comments on B.H. Kim's work on the primo vascular system. J Acupunct Meridian Stud 2012; 5:241-7.

75. Kim HG. Unscientific judgment on the Bong-Han theory by an academic authority in the USSR. J Acupunct Meridian Stud 2013;6:283-4.

76. Liu JL, Jing XH, Shi H, Chen SP, He W, Bai WZ, et al. Historical review about research on "Bonghan System" in China. Evid Based Complement Alternat Med 2013;2013:636081.

77. Lee SH. Different characteristics of the organ surface primo vascular system [dissertation]. Iksan: Wonkwang University; 2011. $68 \mathrm{p}$.

78. Scholkmann F, Shen Y, Ryu PD. Microscopic detection of a red thread-like structure inside primo vessels and primo nodes from the intestine surface of rats. Matters (Zur) 2019. Available from: https://doi.org/10.5167/uzh-177094.

79. Lee BC. Evidence for novel tubular-bundle structures entangled in the fascia of the inner abdominal wall of a rat. Micron 2019; 123:102681.

80. Mustafa FEA. Putative primo-vascular system in rabbit placenta. J Acupunct Meridian Stud 2019;12:20-4.

81. Lim CJ, Yoon YS, Ryu PD. Mesothelial cells covering the surface of primo vascular system tissue. J Acupunct Meridian Stud 2020;13:33-8.

82. Lim CJ, Shen Y, Choi MC, Ryu PD. Primo bundles identified by microcomputed tomography in primo vascular tissue on the surface of rat abdominal organs. J Acupunct Meridian Stud 2020;13:136-45

83. Mustafa FEA, Abdelhafez EA, Abd-Elhafeez HH. Characterization of the primo vascular system in rabbit vagina. Microsc Res Tech 2022;85:799-806.

84. Louveau A, Smirnov I, Keyes TJ, Eccles JD, Rouhani SJ, Peske JD, et al. Structural and functional features of central nervous system lymphatic vessels. Nature 2015;523:337-41. Erratum in: Nature 2016;533:278.

85. Absinta M, Ha SK, Nair G, Sati P, Luciano NJ, Palisoc M, et al. Human and nonhuman primate meninges harbor lymphatic vessels that can be visualized noninvasively by MRI. Elife 2017; 6:e29738.

86. Da Mesquita S, Louveau A, Vaccari A, Smirnov I, Cornelison $\mathrm{RC}$, Kingsmore KM, et al. Functional aspects of meningeal lymphatics in ageing and Alzheimer's disease. Nature 2018;560: 185-91. Erratum in: Nature 2018;564:E7.

87. Benias PC, Wells RG, Sackey-Aboagye B, Klavan H, Reidy J, Buonocore D, et al. Structure and distribution of an unrecognized interstitium in human tissues. Sci Rep 2018;8:4947. Erratum in: Sci Rep 2018;8:7610.

88. Cenaj O, Allison DHR, Imam R, Zeck B, Drohan LM, Chiriboga L, et al. Evidence for continuity of interstitial spaces across tissue and organ boundaries in humans. Commun Biol 2021;4: 436. 